\title{
Regina Beatriz Guimarães Neto Cidades da mineração: memória e práticas culturais: Mato Grosso na primeira metade do século XX
}

Antonio Edmilson Martins Rodrigues*

Cuiabá: Ed. UFMT; Carlini \& Caniato Editorial, 2006. 272p.

Alguns encargos constituem fardos pesados e são resolvidos com má vontade; outros são tão prazerosos que gostaríamos de prolongá-los. Bom exemplo deste segundo caso é a leitura de Cidades da mineração, de Regina Beatriz Guimarães Neto. Construído inicialmente como tese de doutorado, o livro se destaca por ampliar os horizontes e o quadro de reflexões sobre a modernidade brasileira para fora do eixo que comumente os historiadores e cientistas sociais tomam como exemplaridade desse processo de mudanças. A escolha de Mato Grosso como tema de estudo sobre a expansão da urbanização no Centro-Oeste é instigante porque parte das referências teóricas comuns aos estudos da modernidade no Sudeste e, de saída, estabelece com eles um diálogo crítico que alcança o modo pelo qual até agora vem sendo tratada a questão da modernização no Brasil. O diálogo proposto aponta para a periodização que solicita de todas as áreas brasileiras os mesmos elementos para dar-lhes a condição de progresso. Regina Beatriz é dura nas suas críticas ao processo de exclusão de regiões desse horizonte de desenvolvimento.

Para dar ao diálogo crítico maior corpo, transforma o seu estudo em uma busca incessante de compreensão do que estaria para além das estruturas econômicas, sempre apresentadas como elemento definidor da inclusão, ou não, de regiões. Avança introduzindo na análise os elementos culturais, vistos da perspectiva da diversidade de contatos e entendidos como formalizadores de novos traços culturais capazes de dar identidade à região, considerada freqüentemente como uma região de passagem. Disso resulta uma contribuição significativa para os estudos culturais, por sua heterogeneidade, e abre-se ca-

\footnotetext{
*Universidade do Estado do Rio de Janeiro (Uerj) - Pontifícia Universidade Católica - Rio de Janeiro (PUC-Rio). Rua Marquês de São Vicente, 225, Sala 512 F - Gávea. 22453-900 Rio de Janeiro - RJ Brasil. edmilson@puc-rio.br.
} 
minho para que o trabalho possa ser integrado aos estudos sobre expansão de fronteiras, com a singularidade de colocar em jogo as referências da vida, o movimento dos sentimentos e a genealogia da conquista.

É nesse ponto que o livro de Regina Beatriz se mostra mais audacioso. Revela, na linha de Euclides da Cunha, em Os sertões, como a poeira possui traços que podem servir de rastros para a compreensão da realidade.

Mas o desbravamento realizado pela autora vai além e constitui uma das apostas interessantes numa área, ainda desértica, que é a dos estudos de frentes de expansão do Brasil central. Se isso não bastasse, ainda nos oferece outra lição sobre a utilização de fontes produzidas pela metodologia da história oral. A autora nos fornece elementos que, de um lado, nos ajudam a compreender as linhas de ponta dessa metodologia e, de outro, mostram exemplarmente como devemos trabalhar as memórias para que o resultado não seja apenas uma narrativa que tenta atar pontos comuns entre aqueles que falam. Temos aí um instrumento de produção de uma história singular das conquistas e da ocupação do espaço, e seus resultados, combinados com as leituras teóricas - que vão de Deleuze a Ginzburg —, oferecem um 'desenho' do Centro-Oeste. Desenho esse que ultrapassa as formas de simplificação explicativa oferecidas pelas interpretações tradicionais da região.

Com isso, a autora inclui o Centro-Oeste em uma discussão que elimina a sua condição de apêndice de uma economia maior, complemento ou periferia de transformações históricas que construíram a nação brasileira. Nesse sentido, as reflexões contidas no livro auxiliam no entendimento das variadas formas e projetos que estiveram presentes no processo de institucionalização do nacional no Brasil.

Outro ponto de destaque é a forma da narrativa adotada por Regina Beatriz, que nos dá a sensação de vivenciar os fatos e de entendermos os processos, mas que também nos lembra que o historiador deve, antes de tudo, narrar os modos de compreensão de determinado tema. $\mathrm{O}$ historiador deve antes compreender para depois indicar elementos explicativos. Nesse aspecto, a autora oferece uma narrativa que nos envolve no processo de expansão da região, das rotas iniciais de deslocamento, não só de São Paulo e de Minas Gerais, como também de outras áreas. Expõe, assim, a potencialidade da história ali presente, principalmente introduzindo como premissa a constituição das fazendas para logo a seguir mostrar como se estabelecem os caminhos de expansão dos nortistas. Isso é feito com o intuito de demonstrar como esses caminhos definidos pelos tropeiros vão dar origem a cidades, onde predomina a diversidade de culturas. Tais cidades contêm um imaginário fértil que de- 
corre exatamente dessa multiplicidade de presenças, motivo pelo qual elas solicitam a presença da modernização e da civilização.

Esse percurso é realizado no capítulo final do livro, onde estão apresentados "os artifícios da civilidade" e os caminhos que essa solicitação de civilização toma, através das memórias de famílias. Essa linha de reflexão faz que o livro de Regina Beatriz possa se aproximar do texto de referência para a modernidade fora do Sudeste, intitulado Trem Fantasma, a modernidade na selva. Como Francisco Foot Hardmann, a autora desvenda o 'espetáculo' da modernização na selvageria inóspita de espaços conquistados e, com perícia, combina a multiplicidade cultural daqueles que para essa região se dirigiram, reforçando esse processo de compreensão com relação às histórias de vida da região.

Ao final da leitura temos a sensação de que aprendemos algo, de que tivemos contato com novas questões. Isso em um universo editorial em que os livros arriscam cada vez menos, são menos audaciosos e mais despossuídos de teses.

Por isso, Cidades da mineração é uma leitura obrigatória não só para quem pretende ampliar o seu horizonte de conhecimentos sobre a modernidade brasileira e o processo de constituição das cidades da mineração no Mato Grosso da primeira metade do século XX, mas também para quem quer observar como se pode combinar análise e síntese, lembrando a velha, mas cada vez mais oportuna, proposição de Lucien Febvre.

Resenha recebida em março de 2008. Aprovada em março de 2008. 